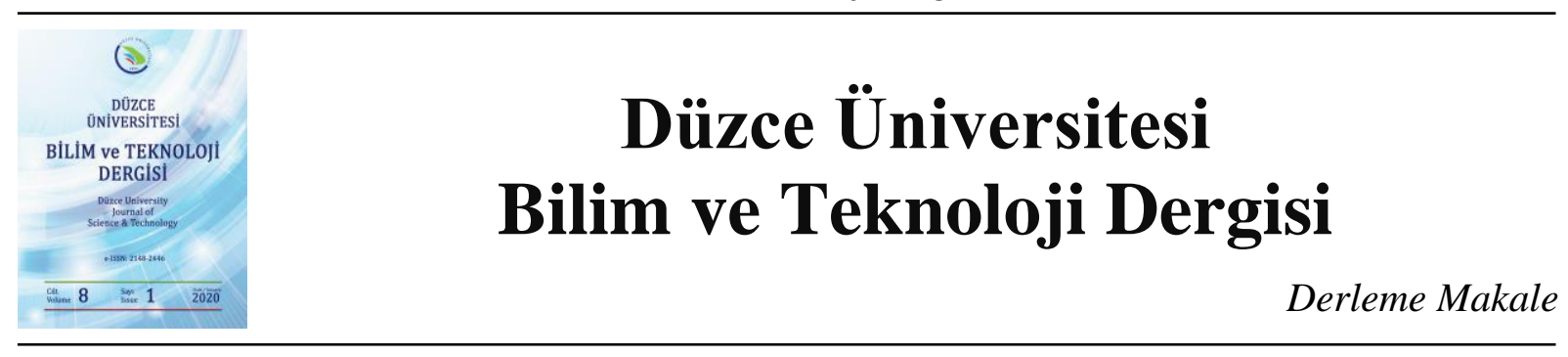

\title{
Doğal Enerji, Sürdürülebilir Kalkınma ve Mimarlık Politikaları
}

\author{
Ali ÇİĞAN ${ }^{a, *}$, (iD Ruşen YAMAÇLI ${ }^{b}$ \\ ${ }^{a}$ Mimarlık Bölümü, Mimarlık ve Tasarım Fakültesi, Eskişehir Teknik Üniversitesi, Eskişehir, TÜRKIYYE \\ ${ }^{b}$ Mimarlık Bölümü, Mimarlık ve Tasarım Fakültesi, Eskişehir Teknik Üniversitesi, Eskişehir, TÜRKIYYE \\ * Sorumlu yazarin e-posta adresi: alicigan@eskisehir.edu.tr
}

DOI: 10.29130/dubited.603746

\begin{abstract}
ÖZET
Doğal enerji kaynaklarının kullanımı ve giderek enerji kaynaklarının tükeniyor olması, bu kaynakların bilinçsizce tüketilmesi, zararlı gazların salınımının artması, küresel ısınma, ozon tabakasının incelmesi, küresel olarak iklim değişikliğine bağlı olarak ekosistemin bozulması çevresel sorunların ortaya çıkmasına neden olmaktadır. İklim değişikliği ve buna bağlı olarak ekolojik dengenin bozulmasında büyük bir paya sahip olan binaların yapım, kullanım ve bertaraf edilme aşamalarının her biri planlı ve doğal hayatı koruma adına yapılmalıdır. Tasarım aşamasından başlayarak, yapım, kullanım ve geri dönüşüm etaplarının her birinde ayrı ayrı alınacak ekolojik ve sürdürülebilir tasarım önlemleri ile yapıların çevreye karşı oluşan olumsuz etkilerinin azaltılması hedeflenmektedir. Çalışmada amaçlanan, mimarlığın temelini oluşturan mimari tasarım ürününe, tasarım sürecinde kullanılan araç ve teknolojilerinin etkileri ile doğal enerji kaynaklarının en üst düzeyde korunması, sürdürülebilirliğinin sağlanması nasıl yapılabilir, bunun için yapılması gerekenler nelerdir ve yapılanların değerlendirilmesi nasıl olmalıdır sorularına cevap aramaktır. Bu amaçlara ulaşmak için yurtiçi ve yurtdışı bazı örnekler incelenmiştir. Sonuçta, gelecekte ortaya konulacak tasarımlara kaynak sağlamak ve en önemlisi mimarinin sürdürülebilir doğal çevrede yerinin belirlenmesi araştırılmıştır.
\end{abstract}

Anahtar Kelimeler: Mimari Tasarım, Ekolojik Mimarlık, Sürdürülebilir Mimarlık, Doğal Enerji, Enerji Etkin Yapı

\section{Natural Energy, Sustainable Development and Architectural Policies}

\begin{abstract}
The use of natural energy sources and the depletion of energy resources, the unconscious consumption of these resources, the increase in the release of harmful gases, global warming, thinning of the ozone layer, the degradation of the ecosystem due to climate change globally cause environmental problems. Each stage of construction use and disposal of buildings, which have a large share in climate change and consequently the degradation of ecological balance, should be carried out in the name of planned and natural life protection. Starting from the design stage, the ecological and sustainable design measures to be taken separately in each of the construction, use and recycling stages are aimed to reduce the negative impacts of buildings on the environment. The aim of the study is to find answers to the questions of how the architectural design product, which constitutes the basis of architecture, the protection of natural energy resources at the highest level, the sustainability of natural energy resources, what needs to be done and what should be done to evaluate the effects of the tools and technologies used in the design process. In order to achieve these objectives, some domestic and international examples were examined. As a result, it was researched to provide resources for future designs and, most importantly, to determine the place of architecture in a sustainable natural environment.
\end{abstract}

Keywords: Architectural Design, Ecological Architecture, Sustainable Architecture, Natural Energy, Energy Efficient Building

Geliş: 08/08/2019, Düzeltme: 26/08/2019, Kabul: 08/11/2019 


\section{GIRIS}

Dünyada giderek artan tüketim odaklı büyüme ile birlikte ortaya çıkan çevresel sorunlar ve ekonomik sıkıntıların giderilebilmesi var olan kaynakların uygun şekilde kullanımı ve enerji tasarrufu odaklı politikalar ve stratejilerin oluşturulmasına bağlidır. Günden güne etkisinin $\operatorname{arttığ~} 1$ görülen çevresel değişikliklere bağlı ekolojik bozulmalar yeryüzünü bütün olarak etkilemektedir. Ani aşırı yağışlara bağlı sel baskınları, uzun süren orman yangınları, sürekli hareket halinde olan toz bulutları gelecek adına pek de olumlu senaryoların yazılamayacağının göstergeleridir. Söz konusu bu olumsuz sürecin yavaşlatılması veya geri alınması bakımından sürdürülebilir olanın tercih edilmesi, çevresel değerlere sahip, var olan enerji kaynaklarına saygılı ve yenilenebilir değerlerle kendi enerjisini üretebilen ekolojik yapıların tasarlanarak hayata geçirilmesi son derece önemli bir hal almaktadır.

Sürdürülebilirlik adına çalışma kapsamının genişliği, var olan kavramların çokluğu, ilkeler arasındaki sıralamanın önemi, bölgesel farklılıkların fazla olması tasarımcıyı doğruyu bulmaya zorlayan etmenlerden bazılarıdır. Sürdürülebilirlikte çalışmaların ortak amacı mimari açıdan incelenmesi, sürdürülebilirliğin doğal çevre açısından değerlendirilmesiyle doğal enerji kaynaklarının korunması ve devamlılığının sağlanmasıdır. Bunun için Türkiye ve dünya ölçeğinde farklı projeler bazında incelemelerin yapılarak, söz konusu enerji tasarrufu boyutunda sürdürülebilir kararların alınması ve bunların geleceğe aktarılmasının sağlanması aranılan temel hedef olmalıdır.

"Az çoktur." (Mies Von Der Rohe) anlayışı; günümüz tasarımcısına malzemenin korunması, sürdürülebilir olması ve enerji etkinlik bakımından çok şey ifade ederken aynı zamanda oluşan üründen de maksimum düzeyde konfor koşullarının oluşturulması gerektiğini aktarmaktadır. Tasarımcı bu anlayış çerçevesinde binalarda en uygun şekilde kaynak kullanımını ön planda tutarken, sonucunda oluşan ürünün de verimli olması için çalışmalıdır. Bu anlayış ile tasarım bir bütün içinde ele alınmalı, tasarım öncesi, yapım aşaması ve sonucunda işletmede oluşan tüm girdi ve çıktıların sürdürülebilirliğe olan olumlu yöndeki gerekliliği vurgulanmalıdır.

Sürdürülebilirlik ve doğal çevre bağlamında mimari tasarım ölçütlerinin neler olduğunun açıklanması üzerine yapılan bu çalışma, yapısal değerlerin oluşumunda meydana gelen çevresel değerlerin bozulmaması ya da kriterler önceliğinde bu bozulmanın minimumda tutulması amacındadır. Çalışma kapsamında günümüz örnek yapılarının incelenmesiyle ortaya çıkan durumun değerlendirilerek yeni binalar için sürdürülebilir tasarım kılavuzu oluşturma amaçlanmış, çevreyle birlikte ve bulunulan çevreden yeni tasarımların oluşturulmasının nasıl yapılabileceği araştırılmak istenilmiştir. Bunun için farklı çalışmalar değerlendirilirken var olan enerji kaynaklarının korunması adına ne tip çalışmaların yapıldığının belirlenmesi ve ortaya çıartılması, çalışmanın temelini oluşturmuştur.

Sürdürülebilirlik bağlamının, süreli bir dizi gözlemler bütünü olması nedeniyle, konu mevcutta olan kaynakların taranması, gündemdeki çalışmaların incelenmesi ve gelecek adına tasarım kriterlerinin neler olabileceği üzerine yapılmış bir derlemedir. Sürdürülebilir tasarımın doğal çevrede uygulanması çok eskilere gitmemekle birlikte günümüzde ele alınması göreceli olmaktadır. Çalışmada konunun sınırlarının belirlenmesi adına sürdürülebilirlik ve doğal çevre bağlamında mimari tasarım ölçütlerinin neler oldukları şekillendirilmektedir.

Yapılan çalışma aşağıda belirtildiği gibi planlanmıştır:

1- İlk olarak çalışma alanının seçilmesinin nedeninin belirlenmesi, bu nedenin çözümü için çalışmanın amaç ve kapsamının açıklanması,

2- Çalışma ana başlıkları ile onları oluşturan alt başlıkların kavramsal anlamda açıklanması, Sürdürülebilirlik ile açığa çıkan kavramsal durumun açıklanabilmesi adına ülkemiz dışındaki örneklerden bir tanesi olan Hassan Fathy tarafından tasarlanmış yapı örneklerinin ele alınarak açıklanması,

3- Sürdürülebilirliğe etki eden yan doğal etmenlerin, bu etmenlerle birlikte mimari kavramların birlikteliği, sonuçta tasarımcının ulaşmak istediği sürdürülebilirlik kriterlerinin temel esas olarak değerlendirilmesi gerektiği, 
4- Sürdürülebilirlik ve doğal çevre bağlamında mimari tasarımda yapı kullanıcılarının farklı ihtiyaçlarına yönelik ve çevresel değerlerin korunarak geleceğe aktarılabilmesini sağlayacak tasarım kriterlerinin oluşturulmasının sağlanması adına tasarımcıya 1şı tutmak istenilmiş ve ayrıca,

5- Sonuçta açığa çıkan durumun yorumlanması ve önerilerin açılanması.

\section{MIMARİ TASARIM VE SÜRDÜRÜLEBILLIR MIMARLIK}

\section{A. MIMARİ TASARIM ve SÜRDÜRÜLEBİLİRLİK}

Tasarım ve mimari tasarım genel olarak pek çok kişi tarafından aynı anlama çekilmekle birlikte esasında farklılık içermektedir. Çeşitli zamanlarda farklı kişiler tarafından bu kavramlar tanımlanmaya çalışılmıştır. Archer, B. tasarımı, "İnsanın çevresini maddesel ve ruhsal ihtiyaçlarına uydurmak için biçimlendirme ile ilgili insan deneyim, beceri ve bilgisinin alanı" [1] olarak görmüştür. Buchanan, R. tasarımı "kendi kişisel ya da kolektif amaçlarını gerçekleştirmek için insanlara hizmet eden ürünlerin düşünülmesi, kavranması, planlaması ve yapılması şeklindeki insan gücü” [2] olarak tanımlamıştır.

Mimarlık mesleği, mimari bir ürün ortaya çıkartılana kadar birçok çalışmanın yapılmasına bağlıdır. Bu çalışmaların iki ana kaynaktan beslendiği kabul edilebilir. Bunlar; tasarım ve inşa. İki kaynak da kendi içerisinde çeşitli alt kaynaklardan beslenirler. Mimari tasarım, Bucciarelli, Goldschmidt ve Schön tarafından "yapmanın özel bir şekli olarak, bir şeyin üretilmesi için bir temsil üretilmesi" [3] olarak tanımlanmıştır. Bunun bir süreç olduğu kabul edilmekle beraber, Mitchell ise, mimari tasarımı özelde yüksek seviyede karmaşık ilişkiler ve kısmen ani ilhamlarla, fakat çoğunlukla deneme yanılmalar ile ilerleyen bir süreç [4] olarak tanımlar. Mimari bir ürünün ortaya konulmasından önce çizimlerinin yapılması, taslağının oluşturulması, gerekli diğer meslek dallarından teknik destekle yoğrulması gerekmektedir. Mimar ve mühendisler, ortaya konulan ihtiyaç programına göre yeterlilik, güvenlik, 1sıtma ve soğutma, aydınlatma ve akustik gibi girdiler ile bütçe ve zaman sınırlarına uygunluk gibi pek çok konuda bilgi sahibi ve tecrübeli olmak zorundadırlar.

Mimarın görevini Perez Gomez "dünyanın rahat ve pratik bir bartnak olarak düzenlenmesinden öte, bakış olarak, söylev ve şiirin anlattı̆̆ içerilik ve müziğin ilettiği ölçülemez uyuma benzer bir insanlık halinin derinliğini yansıtan fiziksel ve biçimsel düzenin oluş̧urulması" [5] olarak tanımlamaktadır.

Mimarlık mesleğinin temeli iletişimdir. Bilinen yazılı ve sözlü iletişim dışında mimar; renk, 1şık, ses, hareket, doluluk ve boşluk gibi çeşitli orantılar ile yaptığı tasarımı ortaya koyar. Sonuçta ortaya koyduğu ürün kendinin parçası olmakla birlikte süreçte yaşadığı birikimi çeşitli araştırma ve sorgulamalar sonucudur. Sonuca varmadan önce yaptı̆̆g eskizler, çizimler, modeller, maketlerin hepsi mimari tasarım için vazgeçilmez araçlardır.

\section{B. MIMARİ TASARIM VE SÜRDÜRÜLEBILİR MIMARLIK}

İnsan, yaşamı gereği ilk gününden beri çevresel değerlerin iyileştirilmesi, geliştirilmesi ve arttırılması adına çalışarak, bunun için gerekli müdahaleleri doğal ortama yaparken aslında yaşamını daha sağlıklı, daha konforlu ve daha zevkli hale getirmek istemektedir. İnsan bu amaçla sınırsız ve tükenmez olarak gördüğü doğal kaynakları hızla tüketmiştir. Süreçte yapılan müdahaleler doğal ortam tarafinda karşılanırken kaynakların hızla tükenmesi insan yaşamı üzerine çeşitli etkiler ortaya çıkartmıştır. Doğal ortamın ve kaynakların tüketilmesiyle insan yaşamı üzerindeki etkilerinin olumsuz olarak ortaya çıkması, insanın kendisini ve doğal ortamı değerlendirirken yeniden sorgulamasına neden olmuştur.

Doğal ortama yapılan müdahaleler sonucu ortaya çıkan çevresel sorunlar ve ekolojik değişimlerle insan yaşam kalitesinin arttırılarak, konfor şartlarının geliştirilmesi, doğal ve enerji kaynaklarının korunması, paylaştırılması ve geliştirilmesini amaçlayan sürdürülebilirlik; doğal ortamın korunması amacıyla ortaya çıkartılmıştır. Sürdürülebilirliğin asıl amacı; doğal çevrenin bozulmasını durdurarak, dengenin yeniden 
kurulması adına çalışmak, bunun için gerekli önlemleri almak ve insan etkilerinin azaltılması adına standartların oluşturulmasıdır.

Sürdürülebilir kavramının pek çok tanımı vardır. Bunlardan başlıcaları;

... "Sürdürülebilirlik, bir toplumun, bir ekosistem veya benzer diğer etkileşimli sistemlerin temel kaynakların tüketmeden ve çevreyi olumsuz etkilemeden devamlı işleme yeteneğidir.” [6].

•.• Sürdürülebilirlik, insanın mevcut çevresel, ekonomik ve sosyal ihtiyaçlarının birlikte ele alınması, bunları bütünüyle karşılayacak şekilde çalışması ve yaşamasıdır.

... İnsana ait zorunlu ihtiyaçlarla, insan dışı diğer canlıların ihtiyaçları arasındaki dengenin kurulmasidir.

•.• Dünyayı iyi koruyalım. Onu dedelerimizden miras almadık, çocuklarımızdan ödünç aldık. (Anonim)

... "Üretimdeki madde ve enerji kullanımında doğanın yenileyici ve emici kapasitelerinin ötesinde büyümeden kalkınma" olarak tanımlanmaktadır [7].

Kaynakların korunması ve gelecek dünyaya aktarılması bakımından sürdürülebilirlik yaşadığımız zamanın temel konusudur. Sürdürülebilir kalkınma, Dünya Çevre ve Kalkınma Komisyonu Başkanı Gro Harlem Brundtland tarafindan açıklanan ve 1987 yılında yayınlanan "Ortak Geleceğimiz- Our Common Future" başl1klı raporda: "Bugünün gereksinmelerini gelecek nesilleri, kendi gereksinmelerini karşılama yetisinden yoksun bırakmadan karşılayarak kalkınma" olarak tanımlanmıştır [8].

"Sürdürülebilirlik denince ilk akla gelen kavramlardan biri de 'ekolojik ayakizi' dir. Bu kavram ilk olarak 1990'ların başında, Kanada'da Dr. Mathis Wacker Nagel tarafindan gelişstirilmiştir. Ekolojik ayakizi, temelde doğal kaynak tüketiminin hesaplanmasını sağlayan bir yöntemdir. Ayakizi analizi ile, bir sistemin, yapının, konutun, vb. biyosferin yeniden üretim kapasitesi üzerindeki etkisi ve kaynak kullanım miktarı ölçülür. Ekolojik kaynakların kullanımının alan birimi (hektar) ile ifade edilmesidir. Bir başka deyişle tüketilen kaynakların yeniden üretilmesi ve atıklarının absorbe edilmesi için doğanın ne kadar kullanıldığını ölçmektedir. Bu değer, küresel toprak arz verilerine dayalı olarak, kişi başına 1.8 hektar olarak hesaplanmıştır." [9]. Sürdürülebilirlik, durağan bir kavram değildir. Günümüze ait yorumlama yaparken ayrıca gelecek için de önerilerde bulunmaktadır. Doğal kaynak kullanımı, teknolojik ve bilimsel gelişmelerle birlikte dönüşüme sahip olan sürdürülebilirlik, bütünüyle bir gelişme sürecidir.

"Sürdürülebilirlik sınırsı gelişim, ilerleme ve tüketim üzerine kurulu dünya düzenine yeni bir bakış açısı getirmekte ve düzenin sürmesi için doğal kaynak ve çevre konularına özen gösterilmesi, korunması gerekliliğini ortaya koyan ve bu konular doğrultusunda, büyümenin bundan sonra nasıl olmasl gerektiğini tanımlayan bir kavramdır. Sürdürülebilir gelişme ile ilgili tanımlar değișen siyasal, toplumsal yapıya ve söz konusu alana (ekonomi, çevre, yapı, kültür vb.) bağlı olarak sürekli gelişmekte ve değişmektedir" [10].

Günümüzde hemen hemen tüm çalışma alanlarında kullanılmakta olan "Sürdürülebilirlik" kavramı, doğal çevrenin bozulmasıyla mimarinin alanına yoğun bir şekilde girmiş ve kullanım alanını (Şekil 1) hızla genişletmiştir. "20. Yüzyılın sonuna doğru "Sürdürülebilirlik" kavramı, mimarların farkındalık alanına girmiş ve mimarlı disiplininde temel bir ilgi alanı haline gelmiştir. Sürdürülebilirlik 21. Yüzyılın da temel konusu olacaktır. Kaynakların korunması ve geleceğe aktarılması önemle üzerinde durulan bir konudur." [11]. 


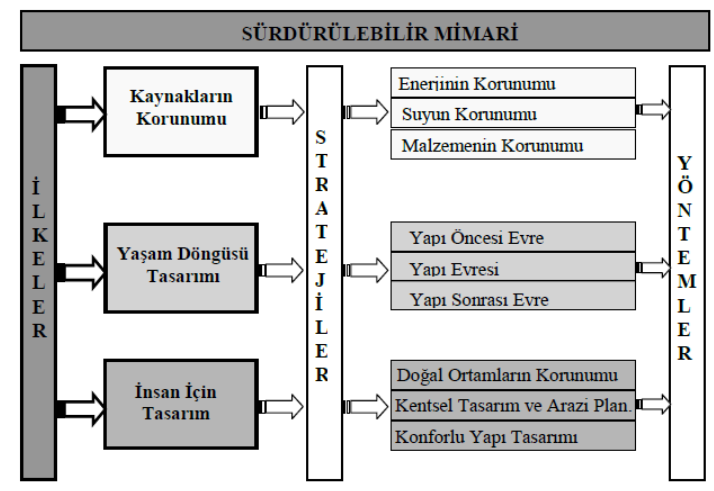

Şekil 1. Mimarllkta sürdürülebilirlik için oluşturulan kavramsal diyagram [12]

Mimarinin sürekli güncel olanı takip etmesiyle sürdürülebilirlik kavramı çelişmemekte, aksine mimaride olduğu gibi sürdürülebilirlik de sürekli güncellenmektedir. Sürdürülebilirlik, mimarinin içine girerken geçmişte yapılanlar ışığında gelişmekte ve bu durum mimariyi yapısal anlamda zenginleştirmektedir. Teknolojik gelişmelerle sürdürülebilir mimari yönünü bulurken, tüm doğal kaynakların korunması ve enerjinin verimli bir şekilde kullanımı ön planda tutulmaktadır. "Sürdürülebilir mimarlık, içinde bulunduğu koşullarda ve varliğının her döneminde, gelecek nesilleri de dikkate alarak, yenilenebilir enerji kaynaklarının kullanımına öncelik veren, çevreye duyarl, enerjiyi, suyu, malzemeyi ve bulunduğu alanı etkin şekilde kullanan, insanların sağllk ve konforunu koruyan yapılar ortaya koyma faaliyetlerinin tümüdür." [13].

Sürdürülebilir mimari, yapısal anlamda genel tasarım kriterlerinin oluşturulması aşamasında doğal olanın kullanılması, taklit edilmesi ya da esinlenilmesiyle başlar ve doğal çevreye doğal olanın tekrar kazandırılmasıyla işlevini tamamlar. Burada ele alınması gereken asıl değer tasarımın esnekliğidir. Esneklikle birlikte yapısal değerler her zaman güncellenirken elde edilen olumsuzluklarında alternatifli bir şekilde değiştirilmesidir. "Sürdürülebilir tasarım, doğal çevreye olan negatif etkileri minimize ederek veya eleyerek, yapılı çevrenin kalitesini maksimize etmeyi araştıran bir tasarım felsefesidir." [14]. En iyi iç ve dış konfor şartlarının oluşturulması uygun aydınlatmaya, havalandırmaya, uygun isı değerlerinin sağlanmasıyla elde edilebilir. Geleneksel tasarım tekniklerinden yola çıkarak oluşturulan mekanların bütün bu değerleri sağlaması için teknolojik verilerin kullanılması gerekmektedir. Doğal kaynakların korunması, çevrenin kirletilmemesi ve doğal çevre döngüsünün sağlanması sürdürülebilirliğin asıl amacı olmakla birlikte mimarlığın, teknolojik değerlerin de girmesi ile amaca ulaşılması daha kolaylaşabilmektedir. Sürdürülebilir mimarlığın amacına bakılacak olunursa, konunun birçok alt başlığa daha sahip olduğu görülmektedir. Enerji, tasarım, üretim, bakım ve onarım maliyetleri, yapıya ilişkin atık ve kirliliğin azaltılması, yapı konforunun arttırılması ancak teknolojik değerlerin kullanılmasıyla sağlanabilir. Shaviv'e göre "Sürdürülebilir mimarlı̆̆ın amacl, çevresine duyarll, az enerji tüketen, çevre üzerinde en az olumsuz etkiye sahip, kullanıcılarına sağglılı iç ortamlar sunan ve konfor koşullarını optimum düzeyde sağlayan binaların tasarlanmasıdır." [15].

Sürdürülebilir mimarlıkta amaç küresel anlamda mevcut veya deforme olmuş ekolojik sistemin korunması, iyileştirilmesi ve geleceğe düzeltilerek aktarılması için çözümler üretmektir. Sürdürülebilir mimari temelde dört ilkede ele alınabilir;

1- Mevcutta bulunan kaynakların en elverişli biçimde kullanımı.

2- Yaşamın devamlılığının sağlanması.

3- Mimari tasarımda insan konforunun arttırılması.

4- Sonuçta yapının uygulaması ve inşası sonrasında ortaya çıkan atıkların geri dönüşümlü olması.

Yapının, tasarım aşamasından kullanımının sonlandırılmasına kadar temelde oluşturulması hedeflenen yukarıdaki ilkelere sahip olması gerekmektedir. Tüm ekosistemin korunması, bu koruma durumunda insan yaşam konforunun oluşturulması ve kaliteli yaşamın sürekliliği günümüzde aranılan esas başlık 
olmakla birlikte sürdürülebilir mimaride amacın bunları kapsaması, geçmişteki sürecin getirdiği gerçeklerle bağdaşmaktadır.

Mimaride sürdürülebilirlik yapısal ürünlerin oluşturulmasıyla gelecek nesillerin kaynak sıkıntısı çekmesini engellerken, onların yaşam konforlarının da en az günümüzdeki gibi ve hatta daha da yüksek olmasını hedeflemektedir. Sürdürülebilir mimarinin kavramsal olarak giderek önem kazanmas1 sürdürülebilirlik kavramının çok yönlü olarak mimariyi etkilemesi sonucudur. Doğal çevreye duyarlı, en uygun verilerle enerji kaynakların kullanılması, geri dönüşümü en üst seviyede olan, insana konforlu ve sağlıklı iç mekanlar sunan yapılar yapılması zorunluluğu ile mimari hep içi içedir. Bu durumda sürdürülebilir tasarımın ekolojik tasarım olarak da adlandırılması mümkündür. Yapı malzemelerinden enerji kullanımı, çevreye asgari düzeyde etki yapacak şekilde ve ekolojiyle birlikte düşünülmeli ve yapılmalıdır. Sürdürülebilirlik adına başarının elde edilebilmesi için söz konusu yapı, mevcut doğal çevreyle birlikte bulunmalı ve onunla birlikte yaşamalıdır.

Foster; "En azla en çoğu gerçekleştirmek, enerjiyi korumak adına bol atık üreten mekanik sistemlere bağıml olmak yerine, yenilenemeyen ve küresel ısınmaya katkı sağlayan kirlilik üreten enerji kaynaklarının kullanımını azaltan pasif mimarlı̆̆ın ideal kullanımı ile ilgilidir. Sürdürülebilirlik iyi mimarlık demektir, mimarlığın kalitesi demektir, kullanılan malzemelerin kalitesinden çok fikirlerin ve düşünce biçimlerinin kalitesiyle ilgilidir. Uzun ömürlü olma, sürdürülebilirlik için önemli bir kriterdir. Uzun ömürlülük ve enerjinin tutumlu kullanımı kriterleri birlikte sağlandiğında sürdürülebilirliğin daha da başarılı bir şekilde gerçekleştirilebileceği açıktır." diyerek sürdürülebilir mimarinin kapsamını, amacını ve gelecek adına nasıl ilerleyeceği hakkındaki düşüncelerini aktarmıştır. [16].

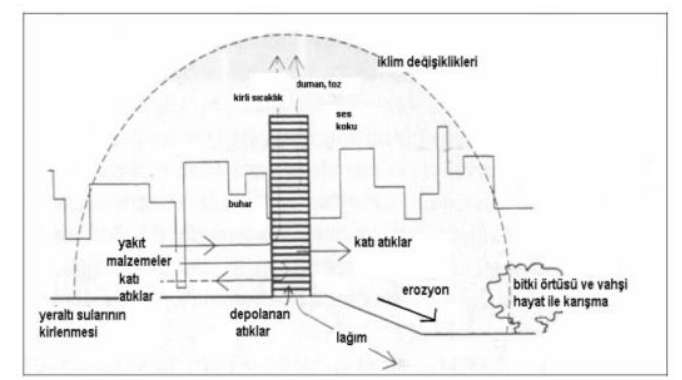

Şekil 2. Yapının çevre üzerine etkileri [17]

Sürdürülebilir mimarlık; ekolojik denge duyarlılık amacıyla insan sağlığını dikkate alan yapı tasarım ve faaliyetlerini amaçlayan bir sistemler bütünüdür. Ekolojik denge duyarlılığı ile yüksek enerji tüketimine sahip binaların daha az enerji tüketmesi, inşasında geri dönüşümlü malzemelerin kullanımı, doğal ve yenilenebilir enerji kaynaklarından yararlanılması durumlarına karşı çözümlerin getirilmesi beklenmektedir. Yapısal olarak sürdürülebilirlik, doğal çevreye verilen zararın (Şekil 2) minimize edilmesi için bir zorunluluktur. Sürdürülebilir mimaride enerji kaynaklarının en etkili şekilde kullanımı ve doğal çevrenin korunması her zaman ön planda tutulmalıdır. Güneş enerjisi, rüzgâr enerjisi, suya bağlı enerji, termal enerji vb. yenilenebilir ve alternatif enerji kaynaklarının kullanımı ile çevreye zararlı enerji kullanımının azaltılması mimaride sürdürülebilirliğin sağlanmasına yönelik önemli ilkelerdendir.

\section{MISIR - HASSAN FATHY PROJELERI}

\section{A. HASSAN FATHY: 1900-1989}

Hassan Fathy, Mısır, İskenderiye'de, 1900 yılında doğmuştur. Fathy, mimarlığa bütün hayatı boyunca bağlı kalmış, kendinden sonra gelen mimar ve plancılara oldukça üstün etkiler bırakan sanatçı ve aynı zamanda şairdir. Meslek hayatının ilk zamanlarında Mısır için endüstri öncesi bina sistemlerinin estetik niteliklerinin neler olduğu üzerinde uğraş vermiş, mevcut iklim kontrolü ve aynı zamanda ekonomiklik 
açısından inşaat tekniklerini öğrenerek, bu tekniklerin kullanımı ile ileriye dönük nelerin yapılabilirliği için çalışmıştır.

Hassan Fathy mimarlık dünyası için sosyal konut anlayışının oluşmasındaki temellerden sayılabilir. Sürdürülebilirliğin, eldeki malzemenin yorumlanmasının, ileriye dönük mekan - zaman insan denkleminin bütünüyle işlenebilirliğinin üzerinde hem yorumlama hem de direkt katkı bakımından belki de dünyadaki herhangi bir mimardan daha fazla kafa yormuş bir kişidir.

Meslek hayatı boyunca yoksullar için çeşitli köyler de olmak üzere onlarca proje tasarlamıştır. Fikirlerinin yanında deneysel ve alışılmışın dışındaki projelerinin büyük çoğunluğu kısmen ya da tamamen gerçekleşmiştir. Tasarımlarında büyük ölçekli kompleks planlamaların yanında küçük ölçekte konut tasarımı da bulmak mümkündür. Fathy, yerelde en değerli malzeme olan kerpiç inşaatı ile Mısır yoksul halkının, kendi güçleri ile bir sığınak yapmak için öğretmen olma ihtiyacı arasında bir bağlantı olabileceği fikrini benimsemiştir.
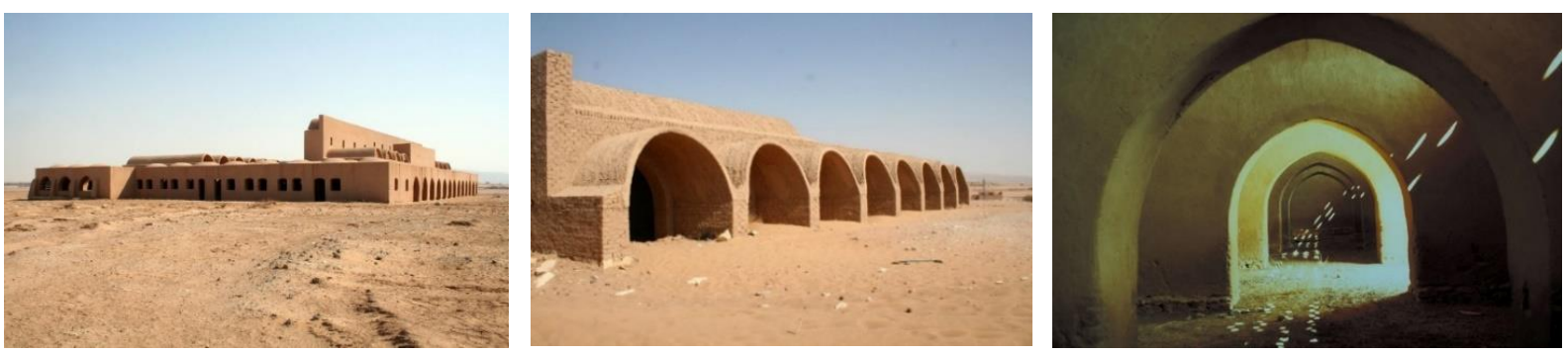

Şekil 3. Mısır'daki yeni Barris Köyü’nden fotoğraflar

Fathy, asgari bir maliyetle yerelde kullanılagelen ve bilinen mekanlar (Şekil 3) yapmak için çalışmış ve böylece yaşadığı dönem kırsal alanlardaki ekonomiyi ve yaşam standartlarını yükseltmek için uğraşmıştır. Bunu yaparken eski tasarım yöntemlerini ve yerel malzemeleri kullanmıştır. Kendi malzemelerini yapmak ve kendi binalarını inşa etmek için yerel sakinleri eğitmiştir. İklim koşulları, halk sağlığ konuları ve eski zanaat becerileri tasarım kararlarına da yön vermiştir. Pasif soğutma sağlamak için yine yoğun tuğla duvarları ve geleneksel avlu formlarını yorumlayarak bilinenin dışına çıkmaya çalışmıştır.

Hassan Fathy yaptığı tasarımlar ile ilgili çeşitli söylemlerde bulunmuştur. Bunlar özetle aşağıda verilmektedir [18].

"Teknolojideki her ilerleme, insanın çevreye hakimiyetine yöneliktir."

"Hayat; Evrenin ritmiyle uyumlu bir şekilde ilişkilendirilmeli, insanın ve mekanik bilimlerin insanın şu andaki bilgi düzeyiyle planlama ve mimari tasarımla olan ayrılmaz ilişkileriyle uyumlu olmalıdır."

Ancak mimarlık sahnesindeki 60 yıllık varlığına rağmen tam olarak anlaşıldığı söylenemez. Tam olarak anlaşılamamakla birlikte en önemli mimari mirası olan hümanizm sayesinde genel anlamda üçüncü dünyaya, özellikle İslam dünyasına, özel anlamda da Mısır'a övünç kaynağı olmuştur. Batının adlandırdığı hiçbir ‘izm’ Fathy’nin mimarlı̆̆ını niteleyememektedir.

Fathy, toplumsal yapı ile mimarlık eylemi arasında birebir ilişkiyi öngören felsefeyi benimsemiştir. "Eğer size 1 milyon sterlin verilseydi ne yapardınız? Bize gençliğimizden beri sürekli sorulan bu soru hayal gücümüzü çalıştırırdı. Bu soruya iki olası cevabım vardı: Birincisi bir yat alıp ve bir orkestra kiralamak ve arkadaşlarımla birlikte Bach Schumann ve Brahms dinleyerek dünyayı dolaşmak; diğeri ise fellahların benim istediğim hayat tarzını sürerek yaşayabilecekleri bir köy inşa etmek [19] . Kültür, insanın çevresine fiziksel ve manevi gereksinimlerini karşılayabilmek için verdiği önemi ve gösterdiği tepkilerdir. Dünyanın farklı yerlerinde çevre ve gereksinimler farklı olduğu için de kültür "değişken"dir" demektedir [20]. 
Fathy'nin en önemli özelliği bir yerde yapı yapmak değil, bir yerden yapı oluşturmaktır. Olanı başka yerden getirmek değil olanı bilgi ve sevgi ile biçimlendirmek olduğunu söylemektedir. Böylece Fathy'nin kullandığı çözümlerde insan doğasına yakın, ucuz ve çevreye zararlı olmayan (Şekil 4) yaklaşımlar görürüz. Hem biçimsel hem teknolojik hem de üretim şekli olarak yörenin geleneklerinden çıkarılan dersler onun mimari pratiğine yön vermiştir.

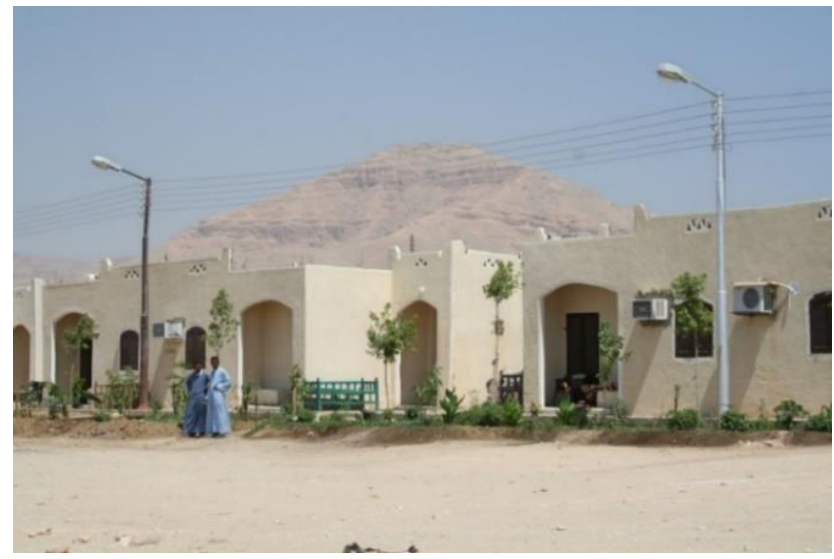

Şekil 4. Yeni Gourna Köyü'nden bir fotoğraf

Hassan Fathy'nin özlemi ve öğretisinden yola çıan ve yoksullar için yerel gereçlerden, küçük bir teknoloji girdisi ile üretilebilen, sürdürülebilir projelerin başarısı için gereken üç temel koşul vardır: Birincisi, bu işi yapacak insanları eğitip yerel bir kapasite oluşturmak; sonra bu kapasitenin sürdürülebilir olabilmesi için parasal ve örgütsel kaynak bulmak; üçüncüsü ve belki de en zoru yerel toplulukların kendilerine sunulan mimariyi benimsemeleridir.

\section{IV.TÜRKIYE'DE YAPILAN İLK DENEMELER}

\section{A. KÖY ENSTITTÜLERİ VE MIMARİ ÖZELLÍKLERİ}

Cumhuriyetin kuruluş yıllarında halkın yüzde 80'inden fazlasının köylerde yaşaması, aşılması gereken en önemli eğitim sorunlarından birini doğuruyordu. Yetişmiş insan azlığı nedeniyle şehirler de bile okullarda öğretmen açığı bulunurken, Maarif Vekaleti'nin köylere öğretmen tahsis etmesi olanaksızdı. $\mathrm{Bu}$ tarihlerde dünya genelindeki ekonomik buhran, tarımsal faaliyetlerin önemini de arttırmıştır. Köylülerin yetersiz kaynaklardan dolayı makineleşmeye geçememesi, tarım konusundaki bilgisizlik üretimi kısıtlayan faktörler olarak görülmekteydi. Tüm bu sorunların yerel imkanlar ile çözülmesi için yapılan tartışmalar ve üretilen eğitim modelleri sonucunda 17 Nisan 1940'ta Köy Enstitüleri Yasas1 çıkarılarak köy okullarında görev alacak olan öğretmenleri yetiştirmek üzere kent ve kasabalardan uzak, tarıma uygun geniş araziler bulunan yerlerde Köy Enstitüleri (Şekil 5) kurulmaya başlanılmıştır.

Köy Enstitülerine ait binaların yapımı için $1940^{*} 1$ yıllarda birçok yarışma düzenlenmiştir. Yarışma şartnamelerinde, yarışmaya katılacak mimarların ilgili bölgede belirli bir süre kalmaları koşulu ile bu yapıların mevcut kültürel dokuya ve iklim koşullarına uygun yapılar olarak projelendirilmelerine (Şekil 6) olanak sağlanmıştır. Enstitü yapılarının yer seçimlerinde, genel olarak ekim ve dikim yapılabilecek geniş alanları bulunan bölgeler ve il merkezleri yolları üzerinde yer alan bölgeler yapım için öncelikli olarak değerlendirilmiştir. Bu model eğitim yapılarında yarışmayla elde edilen projeye göre yapılan ana yapının haricinde, idari birimler, atölyeler, işlikler vb. gibi ana yapıyla ilişkili yardımcı hacimler yer almıştır. Enstitülerde eğitim yatılı olduğundan, öğrencilerin barınma ihtiyacını görecek yatakhaneler, yemekhane, çamaşırhane gibi ek birimler de ana derslik yapısının yanında öncelikli olarak inşa edilen yapılardır. Dönemin rasyonel mimari anlayışında tasarlanan bu yapılar, bulundukları yere göre (Şekil 7) farklı malzemelerle inşa edilmişlerdir. Yapım maliyetlerinin büyük kısmının köy halkı tarafından 
karşılanıyor olması, zamanla Köy Enstitülerine bakışı olumsuz etkilemiş ve bu eğitim yapılarına verilen destek giderek azalmıştır.

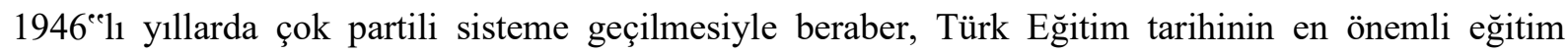
modellerinden olan Köy Enstitüleri projesine son verilmiştir.

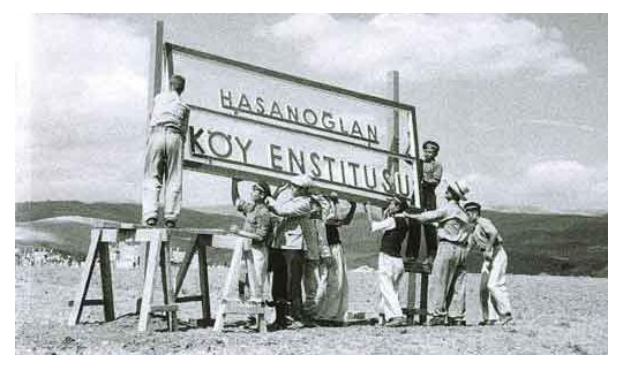

Şekil 5. Hasanoğlan Köy Enstitüsünün kuruluşu

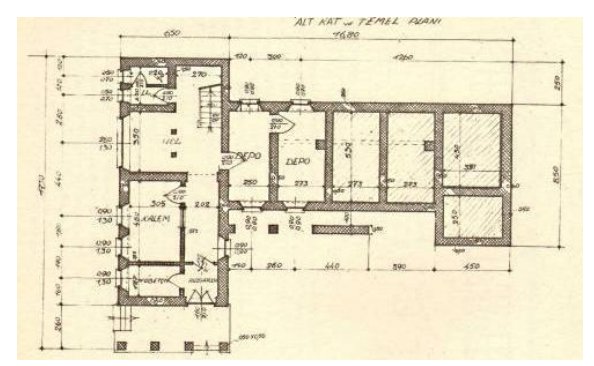

Şekil 6. Pazarören Köy Enstitüsü idari bina planı (Kaynak: Mimarlık ve Kadın Kimliği, Boyut Yayın Grubu)

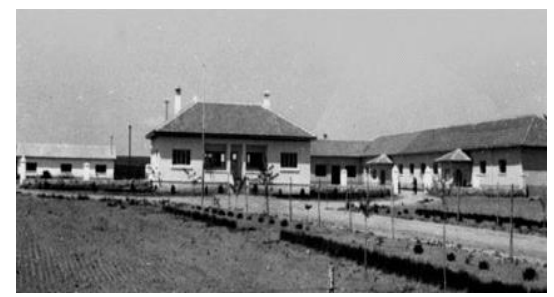

Şekil 7. Leman Tomsu"nun projelendirdiği Hamidiye Köy Enstitüsü.1938-1951 (Kaynak: Mimarlık müzesi veri tabanl)

\section{V.SÜRDÜRÜLEBİIIR MIMARİDE YEREL MALZEMELERIN KULLANILMASI}

\section{A.YEREL MIMARI}

Ekolojik ve sürdürülebilir mimaride yere ait özellikler tasarımın oluşmasında ve şekillenmesinde en önemli konumdadır. Tasarımın yapılacağı yerin iklimsel özellikleri, topoğrafyası ve bitki örtüsü tasarıma yön vermektedir. Tasarımda amaç işlevsel, estetik, ulaşılabilir, dayanıklı yapılar yapmak olduğu için bunların yapılabilirliği yere ait okumanın doğru olmasıyla mümkündür. İnsan için konfor şartları olan bu yapısal özellikler sayesinde doğayla birlikte olan tasarımların oluşması sağlanmış olur. Sürdürülebilir, çevre dostu, doğal tasarımlarla yapı yapılırken mümkün olduğunca doğayı içine alan, ona en uygun şekilde yaklaşan, onunla birlikte yaşarken, doğaya ve yeşil dokuya olabildiğince en az zarar vermek amaçlanmaktadır. "Sürdürülebilir kalkınma; doğal kaynakları, ekonomik yapıyı ve toplumların kendine özgü yapısını içine alan bir dizi yerel koşula göre değişkenlik göstermektedir. 
Sürdürülebilir kalkınma stratejileri kentsel tasarım, ekonomik gelişim, ekosistem yönetimi, ekolojik mimari, enerji korunumu ve çevre kirliliğini önleme gibi çok çeşitli alanlarda uygulanabilmektedir." [21]. Söz konusu stratejiler sürdürülebilirlik adına bulunulan yere, bölgeye, ülkeye ve hatta kıtaya göre değişkenliklere sahipken sürdürülebilir kalkınma tüm bunları gelişim ve kaynak korunumu adına yapmak istemektedir. Yere ait yapısal kararların doğru okunup bunun tasarıma aktarılması sonucu topraktan en uygun şekilde faydalanan, güneşe göre konumlanmış, iklimsel veriler kullanılarak yapılmış yapının; geri dönüşümünün de sağlıklı ve çevreci olacağı kesindir. Geri dönüşüm ile kullanılanın yeniden kullanılabilir duruma getirilmesi, sürdürülebilir tasarım için önemli bir durumdur. Bu sayede âtıl duruma geçmiş, kullanım süresini doldurmuş, işlevsel olarak kullanım sürecine göre değişmesi gereken yapısal etmenlerin işlevsel olarak yapıya yeniden dahil edilmesi sağlanmalıdır. Tasarım sürecinde bu kararların alınması, yapının yapılacağı yere göre farklılaşabilmektedir.

Yapılarda kullanılan malzemenin yakın çevrede bulunup bulunmadığı, üretim-inşa alanı arasında harcanacak enerjiden tasarruf etmek adına oldukça önemlidir [22]. Geleneksel yapım teknikleri ile inşa edilmiş ve yerel malzemelerin kullanıldığı yapılar, tamamen içinde bulundukları ortamın bir ürünü oldukları için doğal ve sürdürülebilir yapılardır. Ekolojik malzemeler; yeniden kullanılabilir, yenilenebilir veya geri dönüştürülebilir malzemelerden oluşmaktadır. Bu tip malzemelere örnek olarak kerpiç, kil, pişmiş toprak, sıkıştırılmış toprak, ahşap, yün, kâğıt paneller, keten, kenevir, deniz yosunu, mantar, moloz, kereste, yeniden kullanılabilir tuğla, kesme taşlar, 1sı izolasyonu için saman balyaları verilebilir. Bambu, çabuk büyüyen çevre dostu bir malzeme olsa da farklı ekolojik kuşaklarda yetişmemekte, sadece yetiştiği çevre açısından ekolojik olma niteliği taşımaktadır. Yapılar bulunduğu konum bakımından ele alınırsa seçilen malzemeler de coğrafi konuma göre çevreyle ilgili malzeme kullanımı açısından farklılaşmaktadır.

Sürdürülebilir mimaride yapının oluşmasına başlanılmadan tasarım aşamasında yere ait kararların doğru ve etkin bir şekilde alınması gerekmektedir. Yapısal form, yere ait durum, yapının yönlenmesi, ölçülendirilmesi, mekânsal iç diziminin yapılması, yapıda kullanılacak malzemelerin yerel olması amaçlanmalıdır. Dış ortama göre farklı koşulların varlığı, tasarımın da farklılaşmasının oluşması doğaldır. Tasarım böylece yapılacağı yere ait olmaktadır. Yapının çevresel verilerle oluşturulması sonucu soğuk iklime göre tasarım farklı şekillenirken, sıcak ve 1lıman iklime göre de farklılık oluşturulmuş olur. Sıcak iklime göre tasarlanan yapının, soğuk iklime göre yapılabilirliği ile soğuk iklim durumunun sıcak iklim verilerine göre değişmesi yerel mimarinin şekillendirilmesinde göz ardı edilemez bir gerçekliktir.

\section{B. SÜRDÜRÜLEBILIIRLIKKTE MIMARIININ YERİ}

Sürdürülebilirlik pek çok farklı alanda, pek çok farklı değerle birlikte kullanılmaktadır. Sürdürülebilirlik kavramının kullanılma yerlerindeki farklılaşması yanında hepsinde ortak olan durum üzerinde durulan ya da çalışılan konunun devamlılık kazanması adına yapılması gerekenler için öncelik olarak gösterilmesidir. Her ne sebeple kullanılıyor olursa olsun sürdürülebilirlik kavramının içi henüz tam olarak doldurulamamıştır. Sürdürülebilirlik ile üzerinde durulan konunun netlik kazanamayacağı anlaşılırken, diğer taraftan amacın ortak olabilirliği olumlu bir yaklaşıma sahiptir. Bu durumun ortaya çıkarttığı zorlukların temelinde de aslında bu yatmaktadır. "Örneğin kıyı yönetimi özelinde incelendiğinde sürdürülebilirlik bugün alanının temel hedefini temsil etmekte ve başarısının ölçülmesi için bir araç olarak görülmektedir. Ancak bu değerlendirme göründüğü kadar basit olmamaktadır. Yakalanması güç bir hedef olan konu üzerine geliştirilmiş çok çeşitli tanımlar, politikalar ve raporlar tartışmayı güçlendirmektedir. Her çalışmada yazarın hedefleri ve gündemiyle birlikte sürdürülebilirliğin bir yorumu yer almaktadır." [24]. Gallager sürdürülebilirlik terimi için yapmış olduğu ankette temel kavramsal ve ilkesel başlıkları tanımlamaya çalışmıştır. Ankete geri dönüşlerde bakıldığı zaman yirmi üç tane alt kavramların ortaya çıktığı görülmektedir. Gallager alt başlıklardan yola çıkarak oluşturduğu yedi "Ana Kavramlar"1 sürdürülebilirlik için temel teşkil edebileceğini iddia etmiştir. Ona göre ortaya çıkan ana ve alt kavramlar Tablo 1'de gösterilmiştir. 
Tablo 1: Sürdürülebilirliğin kavramları [23]

\begin{tabular}{lll} 
Ana Kavram & Alt Kavramlar & Sıralama \\
\hline Denge & Denge, Yaşam Kalitesi, Başarı & 1 \\
\hline Sorumluluk & $\begin{array}{l}\text { Sorumluluk, Önlemler, Düzenleme, Koruma/Kaynak } \\
\text { Verimliliği, Hizmet Etme }\end{array}$ & 2 \\
\hline Planlama & Planlama, Gelecek, Düşünce, Uyarlama & 3 \\
\hline Katılım & Katılım, Kabul Edilebilirlik, Şeffaflık, Güven & 4 \\
\hline Bilimsel Veri & Bilimsel Verim, Problem Çözme & 5 \\
\hline İletişim & İletişim, Eğitim ve Terbiye & 6 \\
\hline Büiünleşme & Bütünleşme, Bütünsellik & 7 \\
\hline Eşitlik & Eşitlik & 8
\end{tabular}

Yukarıdaki çizelgeden yola çıkıldığında sürdürülebilirlik sadece ekolojik, doğal ya da çevresel bir kavram olarak ele alınmamalıdır. Sürdürülebilirlik gelişmeyi, planlamayı, eşitliği ve bilimsel açıdan bütünleşmeyi de içine alan sosyokültürel bir kavramdır. İnsan ilişkileri bakımından değerlendirildiğinde ise birbiriyle dengeli iletişim kurmak ve katılıma kadar pek çok konuyu da içinde barındırmaktadır. $\mathrm{Bu}$ açıdan bakıldığı zaman sürdürülebilirliğin asıl hedeflerine ulaşılabilmesi oldukça güç bir hedef olarak görülmektedir. Bu noktadan hareketle ortaya çıkan sürdürülebilirlik ve onu oluşturan bileşenler aşağıdaki Tablo 2'de özetlenmiştir.

Tablo 2: Sürdürülebilir mimaride aranan başlıklar

Aranılan Koşullar

Tasarımda Alınabilecek Kararlar
Geri Dönüş Biçimi

\begin{tabular}{|c|c|c|}
\hline $\begin{array}{c}\text { Kaynakların Ekonomik } \\
\text { Açıdan } \\
\text { Değerlendirilmesi }\end{array}$ & $\begin{array}{ll}\text { - } & \text { Mevcuttaki Enerjinin Korunumu } \\
\text { - } & \text { Doğal Ortamın Devamlılığııın Sağlanması } \\
\text { - } & \text { Su Ve Yapısal Malzemenin Korunması } \\
\text { - } & \text { En Uygun Biçimde (Isı, Işık, Renk) Tasarım }\end{array}$ & Kaynak Tasarrufu \\
\hline $\begin{array}{c}\text { Yapının Hayata } \\
\text { Geçirilmesi Aşamaları }\end{array}$ & $\begin{array}{ll}\text { - } & \text { Yap1 Tasarım Aşaması } \\
\text { - } & \text { Yap1 Uygulama Aşaması } \\
\text { - } & \text { Yap1 Kullanım Aşaması } \\
\text { - } & \text { Yap1 Geri Dönüşüm Aşaması }\end{array}$ & Kullanıcı Memnuniyeti \\
\hline $\begin{array}{l}\text { Kullanıcının Yapıyı } \\
\text { Benimsemesi }\end{array}$ & $\begin{array}{ll}\text { - } & \text { En Üst Seviyede Konforun Oluşturulması } \\
\text { - } & \text { İnsan Odaklı Tasarımın Yapılması } \\
\text { - } & \text { Ses / Gürülttü Kontrolünün Sağlanması } \\
\text { - } & \text { Doğal Ortam İle Bağlantının Kuvvetli } \\
& \text { Olması }\end{array}$ & $\begin{array}{l}\text { Yapısal Devamlılı̆̆ın } \\
\text { Sağlanması }\end{array}$ \\
\hline
\end{tabular}

Mimarlık ürünü yapıların kullanılmasında, daha verimlilik sağlanması ancak yapısal kararların alınması aşamasında, diğer bir ifadeyle tasarım aşamasında ele alınmasıyla mümkündür. Bunun yanında yapının sürdürülebilirlik yönünden uygun hale getirilmesi için mevcut sisteme çeşitli müdahaleler yapılarak da sağlanabilir. İster tasarım aşamasında olsun, isterse de sonradan yapılan işlemlerle olsun yapı sürdürülebilirlik kimliğini zaman içerisinde ve verilerle kazanmaktadır. Örneğin yapısal atıkların veya suyun yeniden kullanımının sağlanması gibi konular tasarım aşamasında ele alınabilecekken sonradan kullanılan sistemlerin dahil edilmesiyle de yapıya kazandırılabilir.

Günümüz şartlarında doğal ortama göre mimarinin şekillenmesi daha çok teknolojik girdilerle sağlanmaktadır. Diğer bir ifadeyle insan doğal olanı korumak veya ona uygun dille yaklaşmak için dahi yapay olanı kullanmaktadır. Buradaki durum bilginin doğal olan üzerinde kopyalama sağlamasıdır. Yapısal anlamda kullanıcı kimliğinin ve konfor şartlarının oluşturulması mimarın bilgi seviyesine göre değişmektedir. Mimar ne kadar doğal olana hakimse yapacağı tasarımında da bunu ortaya koyacaktır. Tasarımı oluşturan diğer meslek guruplarındaki gelişmelerin mimari olarak değerlendirilmesi de ayrıca yapının doğal çevreye bağl1lığını kuvvetlendirmektedir. 
Doğal ortama göre yapıların tasarlanmasında artan talebin yani müşteri sayısının giderek artıyor olması mimari için büyük bir firsattır. Müşteriler istediklerinde çevreci binalar gerçekleşmekte ve kararları ne kadar güçlüyse yapılar o kadar sürdürülebilir olmaktadır. Üstelik bazen müşterilerin amacı yalnızca elektrik faturalarındaki azalma ve bakım masraflarındaki düşüştür. Bazen de çevreci bir imajın tanıtımı gibi daha az somut bir kâr beklenmektedir [28]. Bunun da nedeni, imaj çağında çoğu zaman görünüşün gerçeklikten çok daha önemli olması ve insanların umursamaz tüketici yaşam tarzlarını sürdürürken vicdanlarını yatıştırmak istemesidir [24]. Bu kapsamda değerlendirildiği zaman doğal olana yaklaşma ve çevreci esaslara oturmuş düşünce kapsamında mimarlı̆̆ın konumunu sorgulamak önemli olmaktadır.

\section{SÜRDÜRÜLEBILLIR MALZEME}

"Sürdürülebilir gelişme, gelecek nesillerin kendi ihtiyaçlarını karşılayabilme becerisini kısıtlamaksızın, günümüzün ihtiyaçlarının karşılandığı gelişmedir." [8]. Buradan yola çıkılacak olunursa sürdürülebilirlik pek çok kavramı kapsamakta, pek çok kavrama altlık oluşturmakta ve pek çok kavramı da içine almaktadır. Doğal çevrenin korunması ve sürekliliği başlığı ile mimari bütünleşmekte olup, sürdürülebilir mimari çevreye duyarlı yapılarda enerjinin verimli kullanılması, doğal çevreye uygun yapılması, mevcut hava kirliliğini arttırmaması, yapıda kullanılan malzemelerin sürdürülebilir özellikte olmas1 gerekmektedir.

Mimarlıkta farklı şekilde tanımlanan çevreci yaklaşımlar bulunmaktadır. Guy ve Moore'a [25] göre, son otuz yıllık süreçte çevre ve mimarlık ilişkisi üzerine birçok kavramsal tartışma yapılmasına karşın bu konuda bir görüş birliği yoktur. Bu yaklaşımlar genel olarak; sürdürülebilir, yeşil mimarlık, ekolojik, enerji-etkin mimarlık gibi farklı şekillerde adlandırılırlar. Steele'ye [26] göre her ne kadar birbirleri yerine kullanılsalar da bu farklı çevreci mimarlık yaklaşımlarından her biri, yaklaşımın adlandırılmasında kullanılan terimin sosyal ve politik anlamları ile ilişki içerisindedir.

Yapıların çevre üzerindeki etkilerinin olumlu olmasında kullanılan malzemelerin niteliği oldukça etkilidir. Malzemelerin ilk hammadde durumundan yapıda kullanılması safhasına kadarki süreçte oluşan atıklar, hava, su ve toprakta kirliliğe neden olmakta ve bu durum doğal çevreyi olumsuz etkilemektedir. Burada yapılması gereken kullanılacak malzemelerin etkilerinin önceden bilinmesi, kullanılacaksa çevre etkilerinin en aza indirgenecek şekilde değerlendirilmesi gerekmektedir. Yapı çevre üzerinde ne kadar az zararlı olursa olsun, mevcut çevre üzerinde mutlaka etkileri olacaktır. Bu sebeple bina inşaasında kullanılan malzemelerin ilk el temininden, revize edilmesi, sahaya getirilmesi, uygun yere montajına kadar enerji tüketimi yapısal anlamda önemli çalışma alanıdır. Yapıyı inşaa etmek için harcanan toplam enerji, yapının inşaasından sonra belli bir dönem kullanılan enerjiye oranla oldukça yüksektir. Bu noktada ortaya çıkan durum ise; sürdürülebilir malzeme ile çevreye duyarlı yapı yapmak, enerji kaynaklarının korunması ve tasarrufu açısından belirgin bir değişim oluşturmamaktadır.

Günümüzde mimarlık dergilerinde çevreci olarak sunulanlar yapıların çoğu, bütün gelişmelere rağmen 1990'lardan pek farklı değildir. Diğer bir ifadeyle günümüz yapıları yakın geçmişimizdeki yapılardan daha da çevrecidir demek doğru değildir. Örneğin eskiden tüm yapıların pencereleri açılmakta ve yapay iklimlendirme 1970'lerin sonuna kadar kullanılmamaktadır [27]. 1980'lere gelindiğinde konu genişlemiş ve yalnızca enerji tasarrufu sağlamak için çalışmalar yapılmamış, yaşama ve çalışma mekanını sağlıklaştırma konuları da gündem olmaya başlamışıtır. Çünkü yapıda kullanılan malzemelerin zehirliliği, yapay iklimlendirmenin olumsuz yönleri, doğal ışı̆̆ın olmaması ve tekrara dayalı işler üzerine kurulmuş eylem alanları, sağlıksız yapıları oluşturmaktadır [28]. Son mimarlık gelişmeleriyle oluşan duruma göre sürdürülebilirlik ve yeşil mimari konusunda genel birlikteliğin sağlandığ söylenemez. Birliktelik açısından kavramsal olarak en genel yaklaşımına örnek, Lehmann'ın yeşil kent tanımı gösterilebilir. Lehmann'a [29] göre yeşil kentin oluşması için gerekli on beş özellik; iklime uyum, yenilenebilir enerji, sıfır atık, su kullanımı, toplu taşıma, kentsel mekanda farklı yaklaşımlar, yerel malzeme, kentsel yoğunluk ile var olan kentsel yerleşimin özellikleri, kentsel biyo-çeşitlilik, pasif iklimlendirme tasarımı, sağlı ve yaşanabilirlik, yerel gıda ve kısa arz döngüleri, kültürel miras, eğitim, gelişmekte olan kentlerdeki stratejiler şeklinde sıralanmaktadır. 
Ekonomik Büyüme ile Sürdürülebilirlik; Parr’a [30] göre bu tanım iki önemli tanımlamayı birbirlerine bağlamıştır. Bu tanımlamalardan ilki "çevre" toplumun yaşadığı yerdir, ikinci tanım olan "kalkınma" ise "çevre" adlı bu "yer"de insanların durumlarını geliştirme çabasıdır ve bu iki kavram bu bağlamda ayrılmaz biçimde birbirlerine bağlanmış olur.

Sürdürülebilirlik kavramının ön plana çıkması sonucu sürdürülebilir kalkınma; ekonomik ilerleme, toplumsal kalkınma ve çevresel etki konuları gibi konular tartışmaların önemli bir maddesi olmuştur. Buradan hareketle sürdürülebilir mimarlık, sürdürülebilir kalkınma hedeflerine uygun mimarlık olarak nitelendirilebilir. Parr [30] sürdürülebilir kalkınma hedeflerine uygun mimarlığ 1 , McDonough ve Braungart'ın [31] Cradle to Cradle kitabında öne sürdükleri görüşler 1şığında, yeşil toplum ve inşa endüstrisi arasında yapılmaktadır. Sürdürülebilir kalkınma bağlamında tartışılan kaynak eşitliği, enerji verimliliği, küresel toplum, yenilenebilirlik, geleneksel bilgi birikimi, güncel teknoloji verilerinin kullanımı gibi konular mimarlık disiplini içerisinde karşılık bulur [26]. 19. yüzyıldan başlayan endüstriyel kirlenme karşısında sosyopolitik akımların mimarlık üzerindeki yansımaları "yeşil mimarlık" düşüncesinin doğmasına neden omuştur. Thoreau'nun [32] metinlerindeki doğa ile bütünleşme ve vahşi yaşama olan sayg1, Schumacher' in [33] "Küçük Güzeldir" kitabındaki "uygun teknoloji" kavramı ve teknolojinin merkez olmadığı sosyal gelişim fikri, yeşil mimarlık kuramının oluşmasında önemli rol oynamıştır. Steele'ye [26] göre, yeşil mimarlığın, sürdürülebilir mimarlıktakine göre somut hedefleri bulunmamasından kaynaklanmakta ve yeşil mimarlık, sürdürülebilir mimarlığın ekonomik ve pragmatik amaçlarından daha fazla, felsefe ve sosyal bilimlerde öne sürülen amaç ve ideallerden etkilenmiştir.

Yapı malzemelerinin enerjiyi koruyan ve bu bakımdan etkin olana yakın olabilmesi ancak doğal kaynakları en az tüketmesine ve enerjiyi en az düzeyde harcamasına bağlıdır. Bu tip malzemelerin yapıda kullanılması ile enerji verimliliğini arttıracak ve böylece sürdürülebilir yapının kazandırılmasına sebep olacaktır.

\section{ENERJİ, KALKINMA VE MIMARLIK İLISSKISİ}

\section{A.ENERJİ VE KALKINMA BİRLİKTELİĞİ}

Enerji, tüm dünyada ortak olarak ele alındığı zaman ekonomik ve toplumsal gelişmenin kaynağıdır. Bu gerçeğe bağlı olarak kalkınmada esaslı bakıldığı zaman enerji, ülke ekonomilerinin gelişmesi ve toplumsal yaşam kalitesinin düzeyinin ne olduğunu yansitıcı bir veridir. Kullanım amacı ne olursa olsun enerji ihtiyacının karşılanabilmesi bütün toplumlar için adil, güvenilir, ekonomik, çevresel değerlere zararsız, yeterli miktarda ve sürekliliği sağlanmış bir şekilde ulaştırılıyor olması ana hedeflerden olması gerekmektedir.

Yaşadığımız dönemde enerji ihtiyacı giderek artmakta ancak bunun tam tersi söz konusu bu ihtiyacı karşılamak için kullanılan enerji kaynakları ise giderek ve yine çok hızlı bir şekilde azalmaktadır. Enerji ihtiyacının ne derece arttığı yayınlanmakta olan bilimsel göstergelerle sürekli ortaya konulmaktadır. 2009 yılında dünyada günlük olarak talep edilen petrol yaklaşık 85 milyon varilken, bu talebin 2030 yılında dünyanın günlük petrol tüketiminin yaklaşık 106.4 milyon varil olacağı öngörülmüştür [34]. Bu oran toplam talebe göre yaklaşık olarak yüzde yirmi beşler seviyesindedir. 2010-2040 yıllarına ait veriler 1şı̆̆ında (Şekil 8) küresel enerji ihtiyacının ortalama yüzde otuz oranında artacağı öngörülmektedir [35]. 


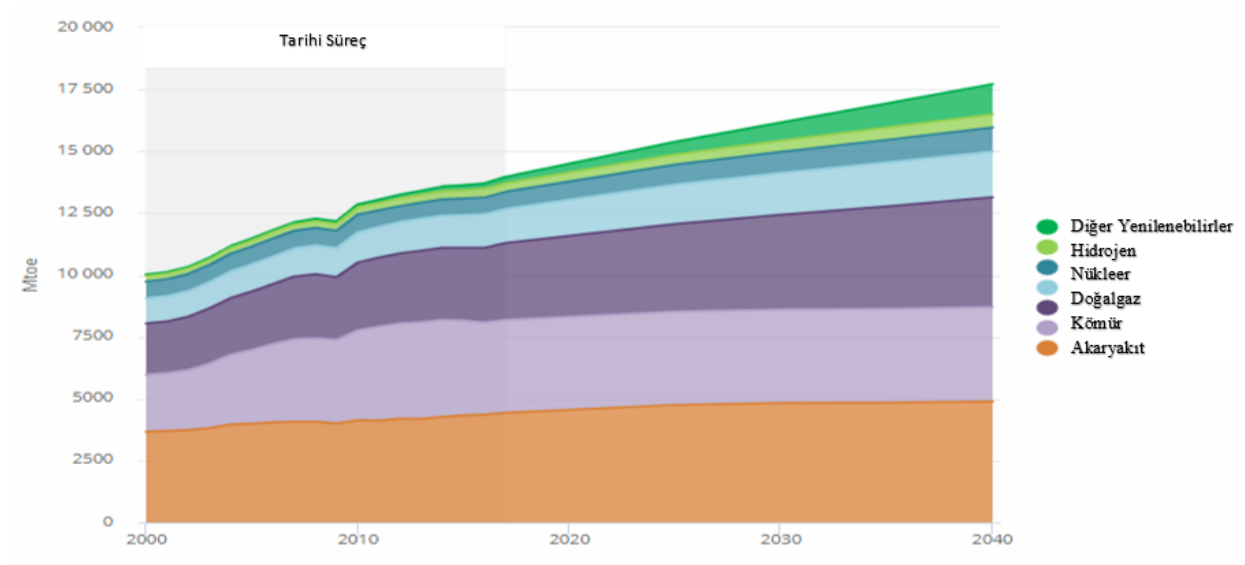

Şekil 8. 2010 - 2040 yılları arasında küresel enerji ihtiyacının değişimi [35]

Mevcut enerji kaynakları sabitken ihtiyacın hızla artması sonucu bu kaynakların daha verimli bir şekilde kullanılması zorunluluğu oluşmaktadır. Enerji ve enerji kaynaklarının verimliliği ve geleceğe aktarımı fikri bu kaynakların devamlılığına bağlı olup bu da sürdürülebilirlik demektir. Sürdürülebilir enerji günümüzde kaçınılmaz bir gerçek haline gelmiştir. Sürdürülebilirlik kavramının tüm dünyada kabul edilmesi Dünya Çevre ve Kalkınma Komisyonunun "Ortak Geleceğimiz" (1987) adlı raporunda belirtilen "sürdürülebilir kalkınma" tanımıyla ortaya çıkmıştır. Buna göre sürdürülebilir kalkınma, "Gelecek nesillerin kendi ihtiyaçlarını karşılama yeteneğinden ödün vermeden bugünün ihtiyaçlarını karşılamak." olarak tanımlanmıştır [36]. Petrol, kömür, doğal gaz, su vb. yenilenemeyen kaynakların kullanılması sonucu ortaya çıkan çevre kirliliği ve buna bağlı olarak oluşan iklim değişikliği gibi sonuçlar, insanların ekonomik, sosyal ve çevresel etkiler bakımından sürdürülemez bir durumla karş1 karşıya kalmalarına neden olmakta ve bu durum sürdürülebilir ve yenilenebilir enerji kaynaklarının kullanımını zorunlu hale getirmektedir. Yenilenebilir enerji kaynağı denilince günümüzde kullanılan güneş, rüzgâr ve jeotermal gibi doğal kaynaklar, yenilenemeyen enerji kaynaklarına ise fosil yakıtlar örnek olarak verilebilir. Enerji kaynaklarının yalnızca yenilenebilir olması yeterli değildir aynı zamanda kaynağın kullanımını sağlayan yöntemlerin de yenilenebilir olması önemlidir. [37]. Enerji kaynaklarının sürdürülebilirliğinin sağlanması ancak yenilenebilir enerji kaynaklarının, enerji verimliliği yüksek teknolojilerle ele alınmasına bağlıdır.

\section{B.MIMARLIKTA ENERJİ ETKİN VE SÜRDÜRÜLEBİLİR KALKINMA İLIŞKİSİ}

Günümüz mimarlığında inşaat sektörü ve buna bağl1 yan birimleri ve bu sektör dünyanın toplam enerji tüketim ortalamasında en büyük paya sahiptir. Dünyada tüketilen enerjinin \%50'si küresel 1sınma nedeni olan sera gazlarından \%50'si, hava kirliliğinden \%24'ü, CFC ve HCFC emisyonlarından \%50'si yapılarla ilişkili faaliyetlerden kaynaklanmaktadır [38]. Bu noktadan hareketle mimarlık saf değildir, bir bütünlük içinde değerlendirilirken girdilerin ve çıktıların öngörülmesi gerekmektedir. Yapısal kararlar sunucu ortaya konulan bina için tüketilen enerji ile ilgili geliştirilecek herhangi bir yaklaşımın gelecek adına atılacak adımlardaki önemi yadsınamaz. Örneğin bu anlayışla, maksimum faydayı sağlamaya olanak tanıyacak şekilde, geri dönüşümü olmayan malzemelerin yapıda minimum seviyede kullanılması büyük bir etki yaratabilir [39]. Mimarinin uygulanması safhasında tasarımdan gelen kararlarla birlikte güncel gelişmelerin kullanılması enerji verimliliği bakımından önemli bir katkı ortaya çıkarır. Enerji kaybının azaltılması, güvenli ve en verimli şekilde taşınması ile gerekli durumlarda kullanılması için depolanmasını sağlayan sistemler günümüzde yaygın şekilde kullanılmaktadır. Son yıllarda mimarlık ile enerji verimliliği ve tasarrufunun sağlanması adına ciddi gelişmeler yapılırken enerji konusunun mimarideki konumu her geçen gün genişlemektedir.

Binalarda enerji verimliliği, enerji ve doğal çevre koruma konusunun gündemde hep güncel olduğu günümüzde mimariye girdiler sağlarken tasarıma da yön verecek konuma gelmektedir. Tasarımın çok boyutlu olması ve bütün girdilerin enerji başlığında birleşmesi ile konunun gelişmesi de 
sağlanabilmektedir. Mimari tasarımının; yapıldığı yere uygun bir biçimde, mümkün olduğunca doğal olan malzemelerle ve enerji verimliliği bakımından da iyi olması gerekmektedir.

Geçmiş dönemlerde enerji verimliliği yüksek ve çevreye uyumlu olan yapıların yapılamaması teknolojik gelişmelerin günümüzdeki kadar olmamasından kaynaklanmaktadır. Söz konusu dönemlerde kaynakların tükenmesi gibi konuların da değerlendirilmesi yapılamadığından girdi ve çıktılar arası değerlendirmeler okunamamaktaydı. Günümüzde ise teknolojik verilerle mimar, enerji konusunda güncel gelişmeleri takip ederken bunları tasarımına kolaylıkla uygulayabilmektedir. Burada esas olan konu enerji ve hammadde kaynaklarının giderek azalıyor olmasıdır. Yapılacak tasarımın uygulanması çoğu zaman teknolojik verilerle yapılırken, geçmişten gelen bir takım alış1lagelmiş pratik çözümlerin de enerji verimliliğinde kullanılması mimara yol göstermektedir. Geçmişten gelen pratik çözümlerin temelinde sürdürülebilirlik anlayışı yatmaktadır. Sürdürülebilirlikte asıl amaç problemin çözümünde devamlılığın sağlanması, yerellikten gelen çözüm yollarının bulunması ve bunun aktarılmasıdır. $\mathrm{Bu}$ noktada birçok mimar gelenekselden hareket ederek sürdürülebilir mimarinin gelişmesi için çalışmıştır.

Yerelden hareketle sürdürülebilir mimarlıkta önemli bir nokta da doğal enerji kaynaklarıyla tasarımın yapılmasıdır. Yerel mimarlığın doğal çevreye olan yaklaşımı ile enerji verimliliği konusu bütünlük içerisinde ele alınabilir. Bu ilişkinin ülke çıkarları doğrultusunda gereksinimlere modern çözümler üretecek politikalarda iş birliği sağlanması önemli olmaktadır. Bunun yapılabilmesi için kurumlar arası öncelikli olmak üzere, sivil toplum örgütleri, araştırma ve yayın gruplarının ortak akılla oluşturacakları süreçlere ortam yaratılmalıdır.

\section{IV.SONUC}

\section{A. GELECEKTEKİ SÜRDÜRÜLEBİLİR TASARIM İLKELERINIIN ÖNGÖRÜLMESİ}

Mimari tasarımda temel amaç; sürdürülebilirlik bakımından yapının tasarım aşamasından ortadan kaldırılmasına kadar olan sürede, yapılan işlemlerin doğal döngüyü bozmadığı kabul edilirse elde edilecek sonuç başarıdır. Yapısal birimden hareketle sürdürülebilirlik açısından kentsel anlamda tasarım aşamasından planlamanın son durumuna kadar olan süre tamamen bir bütündür. Bunun için yapılan çalışmalar sürdürülebilirlik alt başlıkları; fiziksel, çevresel ve sosyo - kültürel sürdürülebilirlik boyutunda ele alınmaktadır. Alt başlıklarla yapının kullanıcı hitap kitlesinin genişletilmesi yani geniş insan sayılarına göre esnek olabilmesi adına yapılmaktadır.

Günümüz hızlı yaşam döngüsü ve çalışma hayatındaki esneklik durumu yapılara aktarılmak zorundadır. Gerek taşıyıcı sistemlerin gerekse son katman malzemelerinin genel anlamda hammadde olarak doğadan elde edilmesi, işlenerek uygun hale getirilmesi ile çevreye verdiği zararın en aza indirilmesi gerekmektedir. Yapısal kararların alınma aşamasında yerel kaynakların ve malzemelerin kullanılması bu noktada son derece önemlidir. Artık yapılardan kış durumunda güneşin yapı içine alınması, yaz durumunda fazla ısının dış ortamda tutulması, mümkün olduğunca doğal havalandırmanın sağlanması, yapay soğutma ve 1sıtma maliyetlerinin azaltılması, kendi enerjisini kendisi üretebilen yapıların ortaya konulması beklenmektedir. Bütün bu beklentilerin yapılabilirliği yanında toplumsal kültürün korunarak devamlılığının sağlanması, insana ait bireysel rahatlığın en uygun şekilde yapılması da zorunluluk olmuştur.

Gelecekteki yapısal sürdürülebilirliğin devam ettirilmesi adına çeşitli alt başlıklar oluşturulabilir. Bunlar kısaca aşağıdaki listelenmiştir.

- İnsanlar arası ilişkinin devam ettirilmesi ve arttırılması adına büyük toplanma mekanları da diyebileceğimiz parklar, meydanlar, açık alanların en uygun biçimde tasarlanması.

- Aynı amaçla açık ve kapalı olarak da kullanılabilecek sosyal tesis, restorant, çeşitli spor tesisleriyle desteklenmiş toplu konutların yapılması.

- İnsan - insan ve insan - çevre ilişkisini kuvvetlendirecek tasarımların yapılması. 
- Çocuklar için yapılabilecek toplu etkileşim ve eğitim yapılarının sayısının arttırılması.

- İnsan yürüme mesafesinde veya bisiklet gibi yakıtsız araçlarla ulaşılabilen sosyal ve toplu kullanımlı yapıların (alışveriş merkezi, sağlık hizmetleri, sosyal tesisler) yapılması, insanın toplu taşıma araçlarına yönlendirilmesi.

- Mevcut yapılardan korunması gerekenlere özel kanun ve yönetmeliklerin uygulanması.

- Toplumsal kültürün korunması adına yerel kaynakların korunmasının sağlanması ve bu bilincin insanlarda oluşması adına eğitimlerin verilmesi.

- Farklı kültürlere ait farklı yerel yapılaşmaların korunmasının ve devamlılı̆̆ının sağlanması.

\section{KAYNAKLAR}

[1] B. Archer, The need for design education, Londra, İngiltere: Royal College of Art Press, 1973.

[2] R. Buchanan, "Design research and the new learning," Design Issues, c. 17 s. 4, ss. 3- 23, 2001.

[3] L. L. Bucciarelli, G. Goldschmidth ve D. Schön, Generic design process in architecture and engineering, Proceedings of the 1987223 Conference on Planning and Design in Architecture, ss. 5964, 1987.

[4] W. J. Mitchell, "A tale of two cities: architecture and the digital revolution," Science, c. 285, ss. 839-841, 1999a.

[5] A. Pérez-Gómez, ve L. Pelletier, Architectural Representation and the Perspectival Hinge, Cambridge, USA: MIT Press. ss. 7, 1997.

[6] K. L. Peterson, J. A. Dorsey, "Roadmap for Integrating Sustainable Design into Site-Level Operations," Pacific Northwest National Lab. (PNNL), Richland, WA, USA, Rap. PNNL-13183 830403000, 2000.

[7] R. Goodland, H. Daly, "Environmental sustainability: Universal and Nonnegotiable," Ecological Applications, c. 6 s. 4, ss. 1002-1017, 1996.

[8] Brundtland Komisyonu, World Commission on Environment and Development Our Common Future, Oxford University Pres, 1987.

[9] S. Roaf, M. Fuentes, S. Thomas, Ecohouse, Architectural Press, 2007.

[10] S. Murcott, "Definitions of Sustainable Development", AAAS Annual Conference, IIASA Sustainability Indicators Symposium, Seattle, WA, USA, 1997.

[11] T. Williamson, A. Radford, H. Bennetts, Understanding Sustainable Architecture, London, UK: Spon Press, 2003.

[12] J. J. Kim, B. Rigdon, Sustainable Architecture Module: Introduction to Sustainable Design, National Pollution Prevention Center for Higher Education, 1998.

[13] A. Sev, Sürdürülebilir Mimarlı, İstanbul, Türkiye: YEM Yayın, 2009.

[14] F. J. Mclennan, The Philosophy Of Sustainable Design, Kansas City, USA: Ecotone Publishing, 2004.

[15] E. Shaviv, "On the use of "solar volume" for determining the urban fabric," Solar Energy, c. 70 s. 3, ss. 275-280, 2001. 
[16] N. Foster, "Lord Foster of Themes Bank," Architectural Design, c. 71 s. 4, ss. 32, 2001.

[17] C.M. Cipolla, Dünya Nüfusunun İktisat Tarihi, İstanbul, Türkiye: Ötüken Neşriyat / Tarih Dizisi, 1992.

[18] Anonim, (2018, 9 Eylül). [Online]. Erişim: https://cals.arizona.edu/OALS/ALN/aln36/Fathy.html

[19] H. Fathy, , Düss ve Gerçek, İstanbul, Türkiye: Boyut Yayınları, 2000, ss. 93-112.

[20] H. Fathy, Hasan Fethi Konuşuyor, Arredamento Dekorasyon, 1990, ss. 89-91.

[21] T. Kutzmark, D. Geis, Developing Sustainable Communities: The Future is Now. Puplic Management magazine, International City/Country Managemant Association, Washington DC for Operation Fresh Start, 2006.

[22] E. Wilhilde, Eco; An Essential Source Book for Environmentaly Friendly Design and Decoration, Universe Pub., 2002. ss. 122-125.

[23] A. Gallager, "Developing a Standard for Sustainability Appraisal in Coastal Management", Proceedings of the Sixth International Conference on the Meditterranean Coastal Environment, ss. 133144, 2003.

[24] P. B. Jones, "Exhibition Eco”, Architectural Review, c. 211, s. 1259, ss. 46-49, 2002.

[25] S. Guy, S. A. Moore, "Introduction: The Paradoxes of Sustainable Architecture," in S. Guy, S. A. Moore (eds.), Sustainable Architectures Cultures and Natures in Europe and North America, New York, USA: Spon Press, 2005, ss. 1-12.

[26] J. Steele, Ecological Architecture: A Critical History, Londra, İngiltere: Thames \& Hudson, 2005.

[27] B. Addis, "Green Gauge”, RIBA Journal, c. 107, s. 7, 2000. ss. 12-16.

[28] H. Beaufoy, "The Green Office In Britain: A Critical Analysis," Journal of Design History, c. 6, s. 3, 1993. ss. 199-207.

[29] S. Lehmann, "Green Urbanism: Formulating A Series of Holistic Principles," Surveys and Perspectives Integrating Environment and Society, c. 4, s. 2, 2012.

[30] A. Parr, Hijacking Sustainability, Boston, USA: MIT Press, 2009.

[31] W. McDonough ve M. Braungart, Cradle to Cradle: Remaking the Way We Make Things, New York, USA: North Point Press, 2002.

[32] H. Thoreau, Doğal Yaşam ve Başkaldırı, İstanbul, Türkiye: Kaknüs Yayınları, 1854.

[33] E. Schumacher, Small is Beautiful, Londra, İngiltere: Vintage Books, 1973.

[34] Anonim, (2019, 16 Temmuz). [Online]. Erişim: https://netfiles. uiuc.edu/mragheb

[35] Anonim, (2019, 25 Temmuz). [Online]. Erişim: http://www.iea.org/publications/ 
[36] Spangenberg, J.H., Sustainable development concepts and indicators, Sustainable Europe Research Institute, 2000.

[37] F. D. Aykal, B. Gümüş, Y. B. Akça, "Sürdürülebilirlik kapsamında yenilenebilir ve etkin enerji kullanımının yapılarda uygulanması," V. Yenilenebilir Enerji Kaynakları Sempozyumu, Diyarbakır, Türkiye, 2009, ss. 78-83.

[38] D. Eryıldız, Sürdürülebilirlik ve Mimarlık Dosyasında Ekolojik Mimarlık, Arradamento Mimarlık Dergisi, s. 154, 2003. ss. 71-75.

[39] W. Liangyong, "Looking Forward to Architecture of the New Millenium," The 4th International Conference of the International Forum on Urbanism (IFOU), Delft, Amsterdam, 2009. 